\title{
Production of Biogas from Paper Waste Blended With Cow Dung
}

\author{
*Nwankwo, Joseph Igwe \\ Department Of Applied Microbiology And Brewing, Faculty Of Applied Natural Sciences, Enugu State \\ University Of Science And Technology, P.M.B. 01660 Independence Layout, Enugu, Nigeria.
}

\begin{abstract}
This research investigated how biogas was produced using paper waste and cow dung. In this study, two digesters were used, one charged with paper waste alone as control and the other charged with cow dung and paper waste. The retention period of the Anaerobic digestion was 44 days, the cumulative biogas yield for paper alone was 210.5 while that of paper blended with cow dung was 322.5, it was found that paper waste alone became flammable within $24 \mathrm{~h}$ while that of the paper waste blended with cow dung takes place on the fifth day, the initial combustion of the paper waste alone was as a result of the initial microbes in the waste. The biogas production from paper drastically stopped after 13 days. The result of the physiochemical analyses shows that the rate of biogas production was been determined by physiochemical properties such as temperature, $p H$, volatile solid and total solid. The organisms that produce biogas are sensitive to $\mathrm{pH}$ and cannot survive below the $\mathrm{pH}$ of 6.5, the biogas was produced under mesophilic condition of $25^{\circ} \mathrm{C}-40^{\circ} \mathrm{C}$. It was observed that the ratio of carbon to nitrogen was between 30:1 and 20:1. The organisms identified after microbial isolation were Micrococcus, Staphylococcus, Escherichia coli and Fungus Aspergillus fumigates, A. niger and penicillium species.
\end{abstract}

Keywords: Biogas, paper waste, cow dung, retention period and anaerobic digestion.

\section{Introduction}

Energy consumption and supply are very essential in evaluating National development and standard of living of any country [1, 2 and 3]. Presently the main sources of energy in Nigeria are coal, crude oil, natural gas, bitumen or tar-sand and grid electricity etc [4 and 6]. They are exhaustible and non-renewable. Interest in renewable energy production is of great importance to any modern nation [7 and 8]. Biogas production can contribute an essential part to a sustainable energy system [9]. In fact, there is a forecast that by the year 2040, fossil fuels would have vanished because of extravagancy in the usage [17]. In addition, grid electricity installation is too expensive especially for rural dwellers and in recent times, the power holding company of Nigeria (PHCN) is not reliable. Since fossil fuels are not renewable or replenish able, the Nigerian Government and indeed other National governments have realized the need to explore other sources of energy that are renewable to meet up with both rural and urban energy demands. Sources of renewable energy are solar energy, wind, solar thermal, photovoltaic and geothermal etc [10,11,12, 13 and 14]. Biogas is a renewable energy that can be generated from biomass wastes such as municipal solid wastes (MSW), sewage sledge, crop residues, energy crops and manure through fermentation or anaerobic digestion. Production of biogas from waste through an aerobic digestion will not only help in solving economic and environmental problems arising from improper use of waste biomass. Energy is essential in all facts of life such as cooking, jumping, riding and so on. Energy can be terminal, radiant (light), mechanical, electrical, chemical and nuclear. There are two sources of energy. Renewable and non-renewable energies [15 and 16]. Renewable energy is energy that can be replenished. Renewable energy technologies such as micro hydro power plants, biomass, wind, photovoltaic's, geothermal generators will provide a real alternative for grid extension in some remote areas and sparsely populated areas of the nation [17]. Hydropower is the largest, most certain and best defined renewable resources for electric system. The technology is matured, reliable and low maintenance in character. Photovoltaic's (PV's) is an elegant and clean form of power generation. As a supplement to conventional source of energy, PV's already have a range of applications with varying degrees of technical and economic feasibility [18 and 20]. This will find application as power supplies to village and decentralized single dwelling for lighting, refrigeration, directdriver, water pumping systems and communication equipment. The useful conversion of natural heat from the interior of the earth to heat building and general electricity is a very exciting application of geologic knowledge and engineering technology [21, 22, 23 and 24].

The justification for this research arises from the fact that streets and homes have become dumping grounds for these wastes thus constituting health hazards for the entire populace. High cost of conventional energy source and erratic Nigeria supply has frustrated the majority of the Nigeria citizen who are in the low income group. It therefore became necessary to look into other sources of energy supply that is renewable and sustainable. Therefore, exploitation of these wastes could provide alternative energy for the entire populace. Hence, the objective of this research was to produce biogas from paper waste blended with cow dung.

\section{Materials and Methods}




\section{Procurement of materials}

The paper waste was procured from a paper publishing company at Nsukka while the cow dung was obtained from the Department of Animal Science, University of Nigeria, Nsukka, Enugu State, Nigeria. Other materials used during the study includes metal prototype digester of 401 capacity constructed at National center for Energy Research and Development, UNN, weighing balance (40kg), (model no ZO51599), Water through graduated transparent plastic bucket (for measuring gas production), Thermometer $\left(-10-110^{\circ} \mathrm{C}\right)$, Jenway digital pH meter (3510), Hose pipes and Bunsen burner fabricated locally for checking flammability.

\section{Wastes treatment}

The cow dung was sprayed under the sun to dry it while the paper waste was squeezed and soaked in water over night.

Charging of Digesters

\section{Experimental set up/charging of wastes}

\section{Paper waste alone digester (3:1)}

$11 \mathrm{~kg}$ of printing paper (Soaked in water) was charged with $33 \mathrm{~kg}$ of water in a ratio of 3: 1 of water to waste. The $\mathrm{pH}$ was 8.6 when biogas production started within $24 \mathrm{~h}$ and commenced flammability of gas on the $1^{\text {st }}$ day, at $\mathrm{pH}$ of 7.6 , flaming stopped after 3days of flammability.

\section{Paper wastes and cow dung digester (1:1)}

Printing paper $(5 \mathrm{~kg})$ and cow dung $(5 \mathrm{~kg})$ making a total of $(10 \mathrm{~kg})$ of wastes, was charged with $30 \mathrm{~kg}$ of water in the ratio of 3:1 of water to wastes, $\mathrm{pH}$ was recorded as 7.5, biogas production started within $24 \mathrm{~h}$ of commencement of flammable biogas production on the $6^{\text {th }}$ day.

\section{Methods of Data Collection and Analyses}

Physiochemical, ultimate and microbial analyses were among the most important analysis carried out on the raw wastes. Physiochemical analysis involved the determination of the major components of wastes under study and they include moisture, fat, ash, $\mathrm{pH}$ and temperature. This analysis provided information relating to practical utility of raw wastes.

\section{Determination of moisture content}

The hot oven air method of AOAC (1990) [ 1] was adopted, porcelain crucibles were washed and dried in an oven at $100^{\circ} \mathrm{C}$ for 30 minutes and these were allowed to cool in the desiccators. Two grammes of raw wastes were placed into weighed crucibles and put inside oven at $100^{\circ} \mathrm{C}$ for $4 \mathrm{~h}$. The samples were removed from the oven after this and were cooled and weighed. The drying was continued and all the crucibles with the samples were reweighed until a constant weight was obtained. The percentage moisture was calculated from the loss of weight of the sample (Ofoefule and Uzodinma, 2006) [24].

\section{Determination of the Ash content of Raw Wastes}

Ash in the organic wastes comprises the residue remaining after all the moisture has been removed, and the fats, proteins, carbohydrates, vitamins, organic acids etc have been burnt away by ignition at a temperature of about $600^{\circ} \mathrm{C}$. It is usually regarded as moisture of the mineral content of raw waste. Employing the AOAC (1990) [1] method, two grammes of the finely ground samples were weighed into porcelain crucibles which have been washed, dried in the oven at $100^{\circ} \mathrm{C}$, cooled in a desiccator and washed. The crucibles containing the samples were placed inside the furnance at $600^{\circ} \mathrm{C}$ for $2 \mathrm{~h}$. After this, the crucibles containing the samples were removed and cooled in the desiccator for 30minutes and then reweighed.

$$
\% \text { Ash } \quad=\frac{\text { Was }+ \text { Wc }}{\text { Ws }} \underline{100}
$$

Where

Was $=$ Weight of ashed sample

$\mathrm{Wc}=$ weight of the crucible

$\mathrm{Ws}=$ weight of the original sample

\section{Determination of the Crude fibre Content}

Crude fibre of the raw wastes is usually determined to have an idea of the materials that are indigestible in the wastes. It is largely made up of cellulose and Lignin. Crude fibre is obtained as organic residue left behind after the raw waste has been treated under standard conditions with organic solvent dilute mineral acids such as $\mathrm{H}_{2} \mathrm{SO}_{4}$, sodium Hydroxide etc. Using AOAC (1990) [1] method, two grammes of the sample were weighed into a $600 \mathrm{ml}$ beaker and mixed with $200 \mathrm{ml}$ of $0.125 \mathrm{~m} \mathrm{H}_{2} \mathrm{H}_{2} \mathrm{SO}_{4}$ and digested for 30 minutes under controlled conditions. The mixture was filtered under suction, washed with distilled water until the washing were no longer 
acidic. The residue was then transferred to a beaker and boiled for 30 minutes with $200 \mathrm{ml}$ of a solution containing $1.25 \mathrm{~g}$ of $\mathrm{NaOH}$ per $100 \mathrm{ml}$. the digested sample was then washed with $1 \% \mathrm{HCL}$ (1g in $100 \mathrm{ml}$ of acid) to neutralize the $\mathrm{NaOH}$ solution and several times with distilled water. The final residue was obtained by filtering through a linen cloth on a fluted funnel. The residue collected was put into a weighed crucible and dried at $100^{\circ} \mathrm{C}$ for $2 \mathrm{~h}$ in the electric oven. It was then cooled in a desiccator, weighed and ashed. The ash obtained was cooled in a desiccators for 30 minutes and weighed

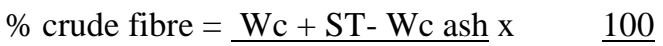

WS

Where

$\mathrm{Wc}=$ weight of crucible

Ws = Original weight of sample

$\mathrm{ST}=$ Treated sample before ashing

\section{Determination of fat Content}

Crude fat content in the wastes was determined using soxhlet Extraction method (pearson, 1976). The soxhlet fat Extraction method involves continuous Extraction of waste sample with non-polar organic solvent such as petroleum ether for 1hour or more depending on the volume of sample in hot oven to dry for 30minutes. It was then cooled in a desiccator. Two grammes of ground wastes sampled was accurately weighed and transferred into a rolled ash filter paper and placed inside the Extractor thimble. The thimble was then placed inside the Soxhlet extractor. Some quality of petroleum ether was poured inside the extract flask and into the condenser. The heater was switched on and set in such a way that the temperature should not exceed the boiling point of petroleum ether used. The Extraction was allowed to run $4 \mathrm{~h}$ after which the petroleum ether was recovered. The oil collected in the flask was dried in an oven at $100^{\circ} \mathrm{C}$. It was weighed and percentage fat calculated as follows:

$\%$ Fat $=\frac{\mathrm{C}-\mathrm{A}}{\mathrm{Ws}} \times \frac{100}{1}$
Where
$\mathrm{C}=$ weight of flask + oil
$\mathrm{A}=$ weight of empty flask

\section{Determination of Total Nitrogen/ Crude Protein in the Wastes}

The Micro-kjeidahl method as described in (Pearson 1976) was used. The method involves estimation of the total nitrogen in the waste and subsequent conversion of the nitrogen to protein with the assumption that all the protein in the waste are present as Nitrogen using a conversion factor of 6.25 , the actual percentage of protein in the waste was calculated as:

$\%$ Crude protein $=\%$ Nitrogen $\mathrm{x}$

\section{Digestion}

Two grammes of the ground waste sampled were weighed into kjeldahl flask. Catalyst such as sodium sulphate and copper sulphate were added in the flask in ratio of 3: 1, oxidizing agent like concentration $\mathrm{H}_{2} \mathrm{SO}_{4}$ $(15 \mathrm{ml})$ was also added. Five glass beads were added to the flask to prevent too much bumping during heating. Heating was carried cautiously on digestion rack under fume cupboard until a greenish clear solution appeared. The digest was allowed to cool. About $10 \mathrm{ml}$ of distilled water was added to avoid caking after which the digest was transferred with several washing into a $25 \mathrm{ml}$ volumetric flask and made up to the mark with distilled water.

\section{Distillation of the protein}

Distillation was carried out using Kjeldahl distillation apparatus. A 50ml receiver flask containing $5 \mathrm{ml}$ boric acid-methyl red and blue indicator was placed under condenser of distillation apparatus so that the tip was $2 \mathrm{~cm}$ inside the indicator. A $10 \mathrm{ml}$ of $40 \% \mathrm{NaOH}$ solution was added to the digested sample in the apparatus through funnel stop cork. Closing the steam by pass and opening the inlet stop cork on the steam jet arm of the distillation apparatus then started off the distillation. The distillate was collected in the conical flask (35ml) with its indicator methyl red and blue. Titration was then carried out using 0.01MHCL to first pink coloration $\%$ Nitrogen $=\underline{\text { Titre } \times 0.0014 \times 250 \times 100}$

Weight of original sample $\mathrm{x} 1$

$\%$ crude protein $=\% \mathrm{~N} \times 6.25$

\section{Determination of Energy}

This was carried out using AOAC (1975)[1] bomb calorimeteric method. It involves igniting the waste sample in adiabatic oxygen Bomb calorimeter (under a high pressure of oxygen gas usually 25 atmospheres). This help to bring about oxidation of organic constituent of the waste sample to water and carbon dioxide while oxidizing some elements such as S,N and P and resultant release of heat. The heat energy that was release was 
used to estimate the energy value of the sample. Two grammes of the sample were pelleted and burnt in adiabatic oxygen Bomb calorimeter. The heat of combustion was calculated as gross energy.

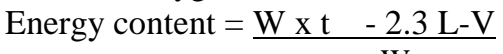

Where

$\mathrm{W}=$ Energy equivalent or water equivalent of calorimeter

$\mathrm{t}=$ temperature rise

$\mathrm{v}=$ titre

Ws = weight of the sample used for Experiment

$\mathrm{L}=$ length of Wire burnt

\section{Determination of Total Solids}

Determination of total solids of waste is an effective way of finding out the amount of nutrient that will be available for bacteria during digestion. It is made up of digestible and non-digestible materials. Five grammes of the raw waste were dried in an oven at $105^{\circ} \mathrm{C}$ for $5 \mathrm{~h}$. The weight obtained after all moisture loss is the total solid.

Therefore

$\% \mathrm{Ts}=\frac{\mathrm{A}-\mathrm{B}}{\mathrm{Ws}} \times \frac{100}{1}$

$\mathrm{A}=$ weight of moisture plus total solids of the sample

$\mathrm{B}=$ weight of moisture lost from the sample at $105^{\circ} \mathrm{C}$.

Ws $=$ original weight of sample

\section{Determination of Carbon content}

One gramme of the finely ground sample was weighed into $500 \mathrm{ml}$ conical flask ten milliliters $(10 \mathrm{ml})$ of potassium dichromate (IM) was poured inside the flask and the mixture was swirled. Twenty milliliters (20ml) of conc. $\mathrm{H}_{2} \mathrm{SO}_{4}$ was added and the flask was swirled again for 1 minute in a fume cupboard. This mixture was allowed to cool for 30minutes after which $200 \mathrm{ml}$ of distilled water, $1 \mathrm{~g}$ of $\mathrm{NaF}$ and $1 \mathrm{ml}$ of diphenylamine indicator were added. The mixture was shaken and titrated with ferrous ammonium sulphate solution in the burette. The blank was also treated similarly.

$\%$ carbon $=\underline{\mathrm{B}-\mathrm{T} \times \mathrm{Cx} 1.33 \mathrm{X} 0.003 \times 100}$

Where,

$\mathrm{B} \quad=$ Blank titre

$\mathrm{T} \quad=$ sample titre

$\mathrm{C}=$ concentration of Fe solution

Ws = weight of waste sample

\section{Measurement of Temperature during the digestion period}

Data logger at the energy center Nsukka was used to record the ambient daily temperature for the period of the experiment. Slurry temperature was recorded with in glass thermometer. (-10 to $110^{\circ} \mathrm{C}$ ) and thermocouple thermometer (Digitron) of model T208/T228/T209 (made in England).

\section{Determination of $\mathbf{p H}$}

The $\mathrm{pH}$ of system under digestion was measured daily and recorded using digital out-put Analog $\mathrm{pH}$ meter of unified National inventory Data base.

\section{Determination of the volume of gas produced}

Water was filled into a white calibrated bucket in litres and the bucket was turned upside down to allow some water to go out, the volume remaining was recorded, then a hose pipe was connected to bucket from the tap of the biogas digester, the tap of digester was then open to release the gas, as the gas is been released it pushes down the water and the volume of water decrease until the gas finishes, the volume of gas produced was then calculated by subtracting the volume of the remaining water in the bucket from initial volume of water which was recorded. The result is the volume of gas produced (Ofoefule and Uzodinma, 2009) [24].

\section{Isolation and Identification}

\section{Microbiological Tests}

Isolation and identification is the most important analysis carried out on the slurry sample to determine the methanogens and other pathogenic organisms E. coli, S. aureus, Candida albicans, Clostridium perfringes and Streptococcus Spp. were present in the slurry that can convert the waste organic matter to methane gas which is flammable. Method used in isolation and identification include media preparation (Nutrient agar, (NA) 
and Sabourand, Dextrose agar plus chloramphenicol, $(\mathrm{SDA}+\mathrm{C})$, culturing incubation and chemical analysis such as Gram staining catalase, coagulase, DNASe, citrate, indole, oxidase and Germ tube tests. Lactophenol cotton blue was used specifically to identify fungi.

\section{Nutrient Agar (NA)}

\section{Media Preparation}

Sixty two grammes of Nutrient agar was suspended in a litre of distilled water and agitated in a flask to have a uniform mixture. It was boiled to dissolve at $121^{\circ} \mathrm{C}$ for 15 minutes. It was allowed to cool to $45-50^{\circ} \mathrm{C}$ and then dispensed $15-20 \mathrm{ml}$ each aseptically into plates.

\section{Sabourand Dextrose Agar plus chloramphenicol (SDA + C)}

The same method used in Nutrient Agar preparation was also used in SDA preparation but chloramphenicol which serves an inhibitor to other organisms and encourage the growth of fungi was added.

\section{Culture and incubation}

The samples were inoculated into the prepared media $(\mathrm{NA}+\mathrm{SDA}+\mathrm{C})$ using sterilized wire loops on the plates near the edge and were spread over the segmented well. The loop was flamed again, on cooling was spread from Area A to area B by streaking method to make sure that streaks do not overlap. The plates were covered and incubated for 2 days at $37^{\circ} \mathrm{C}$ for bacteria and 14 days at $27^{\circ} \mathrm{C}$ for fungi.

\section{Gram Test}

Smears of the pure colonies were made on a clean grease-free glass slides with normal saline. The smears were air -dried and heat -fixed. They were kept on a staining racked positioned in a staining manner and flooded with crystal violet for $1 \mathrm{~min}$ after they were rinsed -off. Lugol was then added for 1 min and immediately rinsed -off. The glass slide were tilted and decolourized with acetone until the drained acetone appeared colourless. They were rinsed off and finally, counterstained with carbol -fushin for 1 min. the glass slides were rinsed -off, blotted, air dried [24].

\section{Motility Test (Hanging Drop Method) and viewed under the microscope}

Peptone water $(3 \mathrm{ml})$ was inoculated with a colony of test organisms and then incubated over night. A ring of plastercine was placed on clean grease -free glass slide and inverted over a drop of the culture broth on the center of a clean cover slip. With quick movement, the slide is inverted so that cover slip is upper most and preparation was examined under the microscope with X10 and X40 objectives. Motility was observed to show an active displacement and time in a given direction (Uzodinma and Ofoefule, 2009 ) [24].

\section{Catalase Test}

A drop of hydrogen peroxide (3\%) was made on clean grease -free glass slide. Using a sterile glass-rod, a $24 \mathrm{~h}$ colony of each of the test organism was picked and smeared on the hydrogen peroxide. Bubble of gas which indicated positive test was observed.

\section{Coagulase Test (Slide Method)}

Fifteen (15) milliliter of healthy human blood was centrifuged and plasma obtained. Thin smears of the test organisms were made on clean grease - free slide at two different sites and a drop of the plasma and water were added respectively to the smears at different sites. The site containing the water served as the control. Clumping of the preparation within 10 s was observed.

\section{Germ tube Test}

The already prepared sterile sugar fermentation medium was heavily inoculated with the test organisms. After overnight incubation at $37^{\circ} \mathrm{C}$, gas production in Durham tube and yellow colouration of the medium were observed [24].

\section{Indole Test (Erhlich's Method)}

A loopfull of the test organisms was cultured into peptone water $(5 \mathrm{ml})$ for 3 days. After the 3 days of incubation, 2 drops of xylene and 3 drop of already prepared indole reagent. (Erhlich's Method) were added to the culture broth. A pink or red ring on the surface of the culture brother was observed as positive test [24].

\section{DNase Test}

DNase agar plates were divided into 3 strips by marking the underside of the plate. The test and control organism were inoculated using a sterile swab making sure that the areas were labeled clearly. After that the plate was incubated overnight at $37^{\circ} \mathrm{C}$. The surface of the plate was covered [24]. 


\section{Results}

The physiochemical properties of the wastes was summarized in table 1: The moisture content in paper waste alone was lower than paper blended with cow dung, the same with ash, fat, and fibre contents, it was also lower in protein, nitrogen and carbon contents, however, the total solid and volatile solid was higher in paper waste alone than paper blended with cow dung. The energy content, $\mathrm{C} / \mathrm{N}$ ratio and $\mathrm{pH}$ values were also higher in paper in waste alone. The lag period, cumulative and mean of gas were presented in table 2: the lag period of paper wastes alone was faster than that of paper and cow dung mixture but cow dung and paper waste mixture yielded more biogas than that paper waste alone. More Microorganism were found in blended paper waste than in paper waste alone at all the stages where viable count was carried out as in table 3 . The daily biogas production was recorded together with the ambient and slurry temperature and it was found out that the higher the temperature, the higher volume of gas yield. Paper blended with cow dung yielded more gas than paper waste alone as shown in fig 1 . In table 5 the following bacterium were present during biogas production, they are Micrococcus species, Staphylococcus aureus, E. coli and Streptococcus species. The fungus that takes part in the biogas production were Aspergillus fumigates, Aspergillus niger and Penicillium species as shown in table 6.

Table 7 shows the yeast isolated and identified during the biogas production, they are Candida albican and Streptococcus species.

Table 1: Physiochemical properties of paper waste alone and paper waste blended with cow dung.

\begin{tabular}{|l|l|l|}
\hline Parameters & Paper -Alone & Paper and cow dung \\
\hline Moisture & 2.85 & 6.2 \\
\hline Ash & 1.55 & 21.3 \\
\hline Fat & Trace & 0.8 \\
\hline Fibre & 70.8 & 53.4 \\
\hline Protein & 1.38 & 8.92 \\
\hline Nitrogen & 0.22 & 1.43 \\
\hline Carbon & 10.77 & 22.74 \\
\hline Total solid & 97.15 & 93.8 \\
\hline Volatile solids & 79.60 & 72.50 \\
\hline Energy & 2.74 & 2.97 \\
\hline C/N ratio & 48.95 & 15.90 \\
\hline p/H at charging & 8.5 & 7.5 \\
\hline
\end{tabular}

Table 2: Lag period, cumulative and mean volume of gas production.

\begin{tabular}{|l|l|l|}
\hline Parameters & Pw-alone & Pw : cd \\
\hline Lag period & $<24$ hours & 5 days \\
\hline Cumulative gas yield & 210.5 & 322.3 \\
\hline Mean volume of gas & 4.78 & 7.33 \\
\hline
\end{tabular}

The large period is the number of days taken for the feed to produce flammable gas from the day of charging to the first day of producing flammable gas, the cumulative of biogas production is the sum of the daily gas production up to the cumulative biogas yield divided by the total retention period of 44 days.

Table 3: Microbial Analysis: (TVC)

\begin{tabular}{|l|l|l|l|}
\hline & Parameters & P W: Alone & PW: CD \\
\hline 1 & At charging & $1.12 \times 10^{6}$ & $8.75 \times 10^{7}$ \\
\hline 2 & At flammability & $6.17 \times 10^{7}$ & $5.62 \times 10^{7}$ \\
\hline 3 & At peak of production & $3.03 \times 10^{7}$ & $8.88 \times 19^{7}$ \\
\hline 4 & At end of digestion & $37 \times 10^{7}$ & $4.58 \times 10^{7}$ \\
\hline
\end{tabular}


Production of Biogas from Paper Waste Blended With Cow Dung

Table 4: Daily Biogas production litres for paper waste alone (PW) and paper waste blended with cow dung.

\begin{tabular}{|c|c|c|c|c|}
\hline Day & Paper waste Alone (PW) & $\begin{array}{l}\text { Paper waste and } \\
\text { (PW :CD) }\end{array}$ & $\begin{array}{l}\text { Ambient } \\
\text { Temperature }\left({ }^{0} \mathrm{C}\right)\end{array}$ & $\begin{array}{l}\text { Slurry } \\
\text { Temperature }\left({ }^{0} \mathrm{C}\right)\end{array}$ \\
\hline 1 & 12.0 Started flaming & Nil & $32^{0} \mathrm{C}$ & $38^{\circ} \mathrm{C}$ \\
\hline 2 & 5.0 & 2.0 & $33^{\circ} \mathrm{C}$ & $36^{0} \mathrm{C}$ \\
\hline 3 & 0.0 & 1.0 & $32^{0} \mathrm{C}$ & $36^{\circ} \mathrm{C}$ \\
\hline 4 & 2.0 & 1.0 & $32^{\circ} \mathrm{C}$ & $32^{\circ} \mathrm{C}$ \\
\hline 5 & 1.0 & 2.0 & $26^{\circ} \mathrm{C}$ & $41^{0} \mathrm{C}$ \\
\hline 6 & 2.0 & 4.2 & $33^{\circ} \mathrm{C}$ & $36^{\circ} \mathrm{C}$ \\
\hline 7 & 1.0 & 5.8 & $33^{\circ} \mathrm{C}$ & $36^{\circ} \mathrm{C}$ \\
\hline 8 & 1.0 & 7.2 & $34^{0} \mathrm{C}$ & $41^{0} \mathrm{C}$ \\
\hline 9 & 1.0 & 9.3 & $33^{0} \mathrm{C}$ & $42^{0} \mathrm{C}$ \\
\hline 10 & 1.0 & 5.9 & $33^{\circ} \mathrm{C}$ & $40^{\circ} \mathrm{C}$ \\
\hline 11 & 1.5 & 5.5 & $32^{\circ} \mathrm{C}$ & $42^{0} \mathrm{C}$ \\
\hline 12 & 3.8 & 4.5 & $32^{\circ} \mathrm{C}$ & $42^{0} \mathrm{C}$ \\
\hline 13 & 5.0 & 8.5 & $33^{0} \mathrm{C}$ & $40^{\circ} \mathrm{C}$ \\
\hline 14 & 5.0 & 8.5 & $32^{\circ} \mathrm{C}$ & $32^{0} \mathrm{C}$ \\
\hline 15 & 5.8 & 7.3 & $26^{0} \mathrm{C}$ & $32^{0} \mathrm{C}$ \\
\hline 16 & 3.0 & 7.5 & $26^{\circ} \mathrm{C}$ & $33^{0} \mathrm{C}$ \\
\hline 17 & \begin{tabular}{|l|}
1.0 \\
\end{tabular} & 3.4 & $32^{\circ} \mathrm{C}$ & $32^{0} \mathrm{C}$ \\
\hline 18 & 6.0 & 11.8 & $33^{\circ} \mathrm{C}$ & $38^{0} \mathrm{C}$ \\
\hline 19 & 6.2 & 7.0 & $32^{0} \mathrm{C}$ & $32^{0} \mathrm{C}$ \\
\hline 20 & 8.0 & 9.4 & $33^{0} \mathrm{C}$ & $43^{\circ} \mathrm{C}$ \\
\hline 21 & 6.5 & 4.0 & $32^{\circ} \mathrm{C}$ & $32^{0} \mathrm{C}$ \\
\hline 22 & 6.5 & 4.0 & $32^{\circ} \mathrm{C}$ & $32^{0} \mathrm{C}$ \\
\hline 23 & 7.0 & 13.7 & $32^{\circ} \mathrm{C}$ & $32^{0} \mathrm{C}$ \\
\hline 24 & 9.5 & 19.1 & $36^{\circ} \mathrm{C}$ & $42^{0} \mathrm{C}$ \\
\hline 25 & 10.0 & 11.8 & $33^{0} \mathrm{C}$ & $42^{0} \mathrm{C}$ \\
\hline 26 & 4.0 & 7.0 & $32^{\circ} \mathrm{C}$ & $42^{0} \mathrm{C}$ \\
\hline 27 & 3.0 & 5.8 & $32^{\circ} \mathrm{C}$ & $42^{0} \mathrm{C}$ \\
\hline 28 & 6.3 & 10.0 & $32^{\circ} \mathrm{C}$ & $40^{\circ} \mathrm{C}$ \\
\hline 29 & 6.0 & 7.8 & $32^{\circ} \mathrm{C}$ & $29^{0} \mathrm{C}$ \\
\hline 30 & 4.0 & 11.0 & $32^{\circ} \mathrm{C}$ & $40^{\circ} \mathrm{C}$ \\
\hline 31 & 3.2 & 8.5 & $32^{\circ} \mathrm{C}$ & $40^{\circ} \mathrm{C}$ \\
\hline 32 & 4.2 & 7.0 & $33^{0} \mathrm{C}$ & $40^{\circ} \mathrm{C}$ \\
\hline 33 & \begin{tabular}{|l|}
3.1 \\
\end{tabular} & 5.0 & $32^{0} \mathrm{C}$ & $40^{\circ} \mathrm{C}$ \\
\hline 34 & 5.0 & 11.7 & $33^{0} \mathrm{C}$ & $40^{\circ} \mathrm{C}$ \\
\hline 35 & 5.0 & 9.0 & $32^{\circ} \mathrm{C}$ & $42^{0} \mathrm{C}$ \\
\hline 36 & 6.5 & 12.0 & $36^{\circ} \mathrm{C}$ & $39^{\circ} \mathrm{C}$ \\
\hline 37 & 6.8 & 11.3 & $32^{0} \mathrm{C}$ & $38^{0} \mathrm{C}$ \\
\hline 38 & 6.0 & 9.3 & $33^{0} \mathrm{C}$ & $42^{0} \mathrm{C}$ \\
\hline 39 & 3.9 & 6.5 & $32^{\circ} \mathrm{C}$ & $38^{0} \mathrm{C}$ \\
\hline 40 & 10.0 & 12.4 & $32^{\circ} \mathrm{C}$ & $42^{0} \mathrm{C}$ \\
\hline
\end{tabular}


Production of Biogas from Paper Waste Blended With Cow Dung

\begin{tabular}{|l|l|l|l|l|}
\hline 41 & 6.0 & 5.0 & $32^{0} \mathrm{C}$ & $40^{\circ} \mathrm{C}$ \\
\hline 42 & 5.5 & 5.0 & $32^{0} \mathrm{C}$ & $40^{0} \mathrm{C}$ \\
\hline 43 & 6.5 & 3.2 & $36^{0} \mathrm{C}$ & $40^{0} \mathrm{C}$ \\
\hline 44 & 6.7 & 4.8 & $32^{0} \mathrm{C}$ & $40^{0} \mathrm{C}$ \\
\hline
\end{tabular}

Table 5: Bacteria identification scheme for the recovered isolates

\begin{tabular}{|c|c|c|c|c|c|c|c|c|c|c|c|c|}
\hline $\begin{array}{l}\text { Sam } \\
\text { ples }\end{array}$ & $\begin{array}{l}\text { Coloni } \\
\text { al } \\
\text { appear } \\
\text { ance }\end{array}$ & $\begin{array}{l}\text { Gra } \\
\text { m } \\
\text { Reac } \\
\text { tion }\end{array}$ & $\begin{array}{l}\text { Cata } \\
\text { lase } \\
\text { test }\end{array}$ & $\begin{array}{l}\text { Coag } \\
\text { ulas } \\
\text { test }\end{array}$ & $\begin{array}{l}\text { Mota } \\
\text { lity } \\
\text { test }\end{array}$ & $\begin{array}{l}\mathrm{D} \\
\mathrm{Na} \\
\mathrm{se} \\
\text { tes } \\
\mathrm{t}\end{array}$ & $\begin{array}{l}\text { Novob } \\
\text { iocin } \\
\text { test }\end{array}$ & $\begin{array}{l}\text { Citr } \\
\text { ate } \\
\text { test }\end{array}$ & $\begin{array}{l}\text { Ind } \\
\text { ole } \\
\text { test }\end{array}$ & $\begin{array}{l}\text { Oxid } \\
\text { ase } \\
\text { test }\end{array}$ & $\begin{array}{l}\mathrm{Ge} \\
\mathrm{rm} \\
\text { tub } \\
\mathrm{e} \\
\text { test }\end{array}$ & Inference \\
\hline $\begin{array}{l}\text { Pape } \\
\mathrm{r} \\
\text { wast } \\
\mathrm{e} \quad- \\
\text { alon } \\
\mathrm{e}\end{array}$ & $\begin{array}{l}\text { Cluster } \\
\mathrm{s} \text { of } \\
\text { mediu } \\
\mathrm{m} \text { size } \\
\text { coloni } \\
\text { es on } \\
\mathrm{NA}\end{array}$ & $\begin{array}{l}+\mathrm{ve} \\
\text { Rod }\end{array}$ & $+\mathrm{ve}$ & -ve & $-v e$ & $\begin{array}{l}- \\
\text { ve }\end{array}$ & $+\mathrm{ve}$ & -ve & -ve & -ve & -ve & $\begin{array}{l}\text { Micrococ } \\
\text { occus } \\
\text { Spp }\end{array}$ \\
\hline $\begin{array}{l}\text { Pape } \\
\mathrm{r} \\
\text { wast } \\
\mathrm{e} \\
\text { alon } \\
\mathrm{e}\end{array}$ & $\begin{array}{l}\text { Mediu } \\
\mathrm{m} \text { size } \\
\text { coelav } \\
\text { aeted } \\
\text { cream } \\
\mathrm{y} \\
\text { coloni } \\
\text { es on } \\
\mathrm{NA}\end{array}$ & $\begin{array}{l}\text { +ve } \\
\text { Cocc } \\
\mathrm{i} \text { in } \\
\text { clust } \\
\text { er }\end{array}$ & $-\mathrm{ve}$ & $-\mathrm{ve}$ & $-\mathrm{ve}$ & $\begin{array}{l}- \\
\text { ve }\end{array}$ & $-\mathrm{ve}$ & -ve & -ve & $-\mathrm{ve}$ & -ve & $\begin{array}{l}\text { Staphylo } \\
\text { coccus } \\
\text { spp }\end{array}$ \\
\hline $\begin{array}{l}\text { Pape } \\
\mathrm{r} \\
\text { wast } \\
\mathrm{e} \\
\text { and } \\
\text { cow } \\
\text { dung }\end{array}$ & $\begin{array}{l}\text { Small } \\
\text { flat } \\
\text { pale } \\
\text { coloni } \\
\text { es on } \\
\text { NA }\end{array}$ & $\begin{array}{l}+\mathrm{ve} \\
\text { cocci } \\
\text { in } \\
\text { chins }\end{array}$ & $-\mathrm{ve}$ & $-\mathrm{ve}$ & $-\mathrm{ve}$ & $\begin{array}{l}- \\
\text { ve }\end{array}$ & $-\mathrm{ve}$ & -ve & -ve & $-\mathrm{ve}$ & -ve & $\begin{array}{l}\text { Staphylo } \\
\text { coccus } \\
\text { Spp }\end{array}$ \\
\hline $\begin{array}{l}\text { Pape } \\
\mathrm{r} \\
\text { wast } \\
\mathrm{e} \\
\text { and } \\
\text { cow } \\
\text { dung }\end{array}$ & $\begin{array}{l}\text { Cicula } \\
\mathrm{r}, \\
\text { convex } \\
\text { smoot } \\
\mathrm{h} \\
\text { coloni } \\
\text { es with } \\
\text { discrat } \\
\text { e egde } \\
\text { on NA } \\
\end{array}$ & $\begin{array}{l}\text {-ve } \\
\text { Rod }\end{array}$ & -ve & -ve & -ve & $\begin{array}{l}+\mathrm{v} \\
\mathrm{e}\end{array}$ & $-\mathrm{ve}$ & -ve & -ve & $+\mathrm{ve}$ & -ve & E.coli \\
\hline $\begin{array}{l}\text { Pape } \\
\mathrm{r} \\
\text { wast } \\
\mathrm{e} \\
\text { and } \\
\text { cow } \\
\text { dung }\end{array}$ & $\begin{array}{l}\text { Cluster } \\
\mathrm{s} \text { of } \\
\text { mediu } \\
\mathrm{m} \text { size } \\
\text { coloni } \\
\text { es NA }\end{array}$ & $\begin{array}{l}+ \text { ve } \\
\text { Rod }\end{array}$ & $+\mathrm{ve}$ & -ve & $-\mathrm{ve}$ & $\begin{array}{l}- \\
\text { ve }\end{array}$ & $+\mathrm{ve}$ & -ve & -ve & $-\mathrm{ve}$ & -ve & $\begin{array}{l}\text { Micrococ } \\
\text { cus } \\
\text { Spp }\end{array}$ \\
\hline $\begin{array}{l}\text { Pape } \\
\mathrm{r} \\
\text { wast } \\
\mathrm{e} \\
\text { and } \\
\text { cow } \\
\text { dung }\end{array}$ & $\begin{array}{l}\text { Mediu } \\
\mathrm{m} \text { size } \\
\text { elevate } \\
\mathrm{d} \\
\text { cream } \\
\mathrm{y}\end{array}$ & $\begin{array}{l}++ \\
\text { cocci } \\
\text { in } \\
\text { clust } \\
\text { ers }\end{array}$ & $+\mathrm{ve}$ & $+\mathrm{ve}$ & $-\mathrm{ve}$ & $\begin{array}{l}+\mathrm{v} \\
\mathrm{e}\end{array}$ & $-\mathrm{VE}$ & -ve & -ve & $-\mathrm{ve}$ & -ve & $\begin{array}{l}\text { Staphylo } \\
\text { coccus } \\
\text { aureus }\end{array}$ \\
\hline
\end{tabular}


Table 6: Yeast Identification scheme for the recovered isolates

\begin{tabular}{|l|l|l|l|l|}
\hline SAMPLE & $\begin{array}{l}\text { GRAM } \\
\text { REACTION }\end{array}$ & $\begin{array}{l}\text { GERM } \\
\text { TUBE }\end{array}$ & ODOUR & INFERENCE \\
\hline $\begin{array}{l}\text { Paper waste } \\
\text { alone }\end{array}$ & $\begin{array}{l}\text { Gram } \\
\text { Positive } \\
\text { (bud) }\end{array}$ & +VE & Fermented cassava smell & Candida albicans \\
\hline $\begin{array}{l}\text { Paper waste } \\
\text { alone }\end{array}$ & Gram Positive (bu) & -VE & Foul & Saccharomyces spp \\
\hline
\end{tabular}

Table 7: Identification scheme for the recovered fungi isolates

\begin{tabular}{|c|c|c|c|}
\hline SAMPLE & $\begin{array}{l}\text { COLONIAL } \\
\text { APPERANCE ON } \\
\text { SDA } \\
\end{array}$ & LACTOPHENOL COTTON & INFERENCE \\
\hline $\begin{array}{l}\text { Paper } \\
\text { Alone }\end{array}$ & Greenish colouration & $\begin{array}{l}\text { Septate hyphane condiophore's born } \\
\text { laterally on the hyphae, non septate, } \\
\text { Numerous sterigmata proceed from the } \\
\text { apical club-shaped swellings, condia } \\
\text { born in chains of the sterigmata }\end{array}$ & A. fumigates \\
\hline $\begin{array}{l}\text { Paper } \\
\text { Alone }\end{array}$ & $\begin{array}{l}\text { Grayish, colouration } \\
\text { with white boards }\end{array}$ & $\begin{array}{l}\text { Septate hyphae condida borne on the } \\
\text { condiophores in multi-link chains like } \\
\text { paint brush }\end{array}$ & Penicillus SPP \\
\hline Paper & Greenish colouration & Septate hyphaeconi & A.fumigatus \\
\hline $\begin{array}{l}\text { Waste } \\
\text { and } \\
\text { cowdung }\end{array}$ & & $\begin{array}{l}\text { Diphores born laterally on the hyphae, } \\
\text { non-septate numerous sterigmata } \\
\text { proceed from the apical club shaped } \\
\text { swelling condia born in chains of the } \\
\text { sterigmata }\end{array}$ & \\
\hline \multirow[t]{2}{*}{$\begin{array}{l}\text { Waste } \\
\text { and } \\
\text { cowdung }\end{array}$} & $\begin{array}{l}\text { Grayish, colouration } \\
\text { with white beardes }\end{array}$ & $\begin{array}{l}\text { Septate hyphane condia borne on the } \\
\text { condiophores in multi- link chain like a } \\
\text { paint brush }\end{array}$ & Penicillum SPP \\
\hline & Blackish colouration & The same with that of a fungus & Aspergillus nige \\
\hline
\end{tabular}

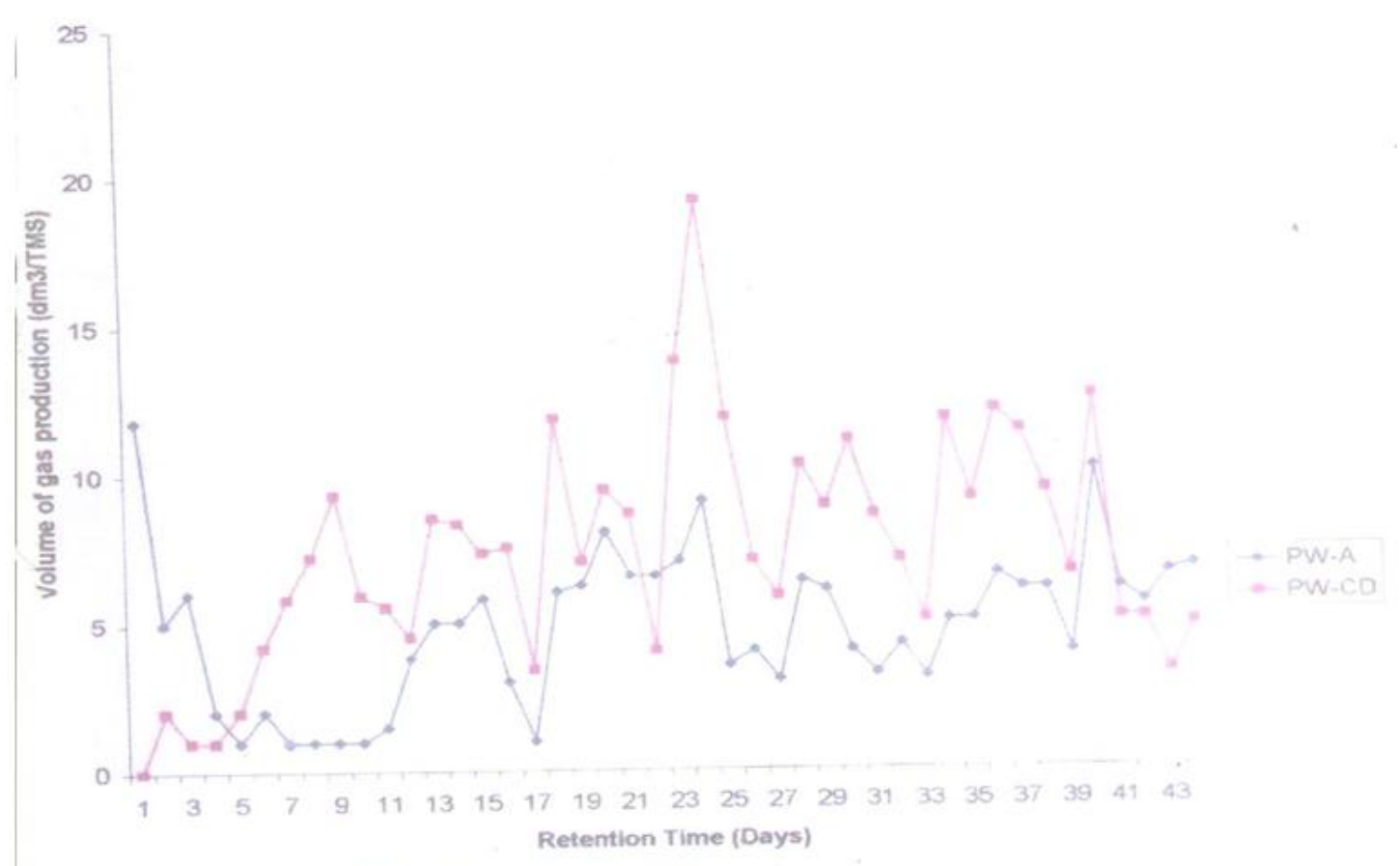

Fig. 1: Daily Biogas Production

The result of the daily biogas production is shown in the figure 6 above as recorded in table iv 


\section{Discussion}

The experiment was carried out under ambient range of $26-36^{\circ} \mathrm{C}$ and slurry temperature of 32 to $42^{\circ} \mathrm{C}$ with the retention time of 44days, it was found that the higher the temperature the higher the volume of gas produced, this is because temperature affects the microorganisms responsible for the biogas production which are mostly mesophilic organisms. The onset of flammability in paper waste alone was faster than the paper waste blended with cow dung this is because of the initial microbes present in the waste [2], [3], [4] and [5]. The cumulative biogas yield was higher in paper blended with cow dung digester because cow dung increases the growth of the physiochemical properties of the waste and encourages the growth of the microbes responsible for the biogas production [24]. The $\mathrm{C} / \mathrm{N}$ ratio has been given to be optimum in the range of 20-30:1 this is because the Methagenic microbes that converts wastes to biogas takes up carbon 30 times faster than nitrogen [20] and [23]. The results also shows that apart from methanogenic microbes that produce the biogas other pathogenic organisms were also present in the biogas slurry such as Staphylococcus aureus, E.coli and Streptococcus species therefore biogas producers should be careful to avoid contamination of diseases.

\section{Conclusion}

This study has shown that paper wastes which abound everywhere including printing presses could be a very good stock for biogas production. This waste can be utilized to generate energy instead of burning them up or littering them in the environment which constitute nuisance to the environment. The study also shows that blending paper waste with cow dung or any other animal waste will give steady gas flammability throughout the digestion period of the waste since animal wastes are good producing wastes.

\section{Recommendations}

As a result of the findings in this aspect of technology, the following recommendations were made:

- The universal adjunct such as cow dung and pig dung should be added to other organic wastes during anaerobic digestion to increase biogas yield.

- Study of waste- adjunct ratio for optimal production of biogas is necessary.

- Maintenance of optimum mesophilic temperature of biogas production in tropics is necessary to boost yield round the seasons of the year.

- More research should be carried out in the commercialization of the bio-fertilizer an important waste left after bio-degradation of organic.

- Adequate values and regulators should be designed for bottling biogas

- Design and construction of equipment that would be attached to fixed dome digester system whereby volume of gas production could easily be read without using water displacement method.

- Further purification of biogas should be carried out to enhance other applications of the world.

- Design and fabrication of biogas burners are necessary to facilitate development and dissemination of the stored gas and thus encourage its wide utilization in this part of the world.

\section{REFERENCES}

[1] AOAC (1990). Official methods of Analysis. Association of Analytical Chemists (14 ${ }^{\text {th }}$ edn.) Arlingron, Virginia, Pp 222

[2] Enwere, J.I (2000). Design, Construction and performance testing of batch operated biogas plant using agricultural residues PHD thesis (Unpublish), University of Nigeria Nsukka.

[3] Ezeonu , F.C, Udedi, S.C, Okonkwo, C.J and Okaka, A.N.C (2000). Studies on Brewer's spent grain biomethanation: 1, optimal conditions for Anaerobic Energy, 10(1\&2): 53-57.

[4] Eze, J.I, Onwuka, N.D and Okeke, C.E (2003). Generation of biogas from brewery Effluent. Journal of Solar Energy, 14: 115-120.

[5] Enwere, J.N (1998). Food of plant origion. Nigeria: Afro-orbis publication Ltd.

[6] Garba, B. Zuru, A and Sambo, A.S (1996). Effect of slurry concentration on biogas production from cattle dung. Nigeria journal of Renewable Energy .4(2): 38-43.

[7] Garba, B. Ojukwu, U.P. (1998). Biodegradation of water hyacinth (Erchormia crayspies). An alternative source of fuel. Nigeria journal of Renewable Energy 6 (1 \& $20: 12$-15).

[8] Ganiyu, O . (2005). Isolation and characterization of amylase from fermented cassava waste water. African journal of Biotechnology 4 (10): 117-1123.

[9] Asia - pacific Environmental innovation strategies, APEIS (2001). Research on innovative and strategic policy options, Good practices inventory : Office of Energy policy and planning. The Ammasat University, Department of industrial works, Asia palm oil Company.

[10] Effiok, W.W (2004). Contaminants and residues in food Industries in Nigeria NAFDAC, Nigeria.

[11] Zuru,A, Saidu, H, Odum, E.A and Onwurah. O. (1998). Comparative study of Biogas production from horse, goat and sheep dung. Nigeria Journal of Renewable Energy, 6 (1 and 2): 43-47.

[12] Werecko, B, Charles, Y and Essel, B.H (1996) Biomass Conversion and Technology. Center for Energy and Environmental Development Ghana: John Wiley and Sons Ltd.

[13] Srinivasan, S.V. Jayanthis, S. and Sundarajan, R (1997). A system approach to biogas technology from “ Biogas technology: a training manual for extension.

[14] Sustainable development (SD) dimension (1997) synergistic effect of kitchen.

[15] Dioha, I.J, Umar, M.K, and Okoye, P.A.C (2003). Studies of qualitative and quantitative yields of biogas from cow dung and poultry droppings. A paper for presentation at National Energy Forum, NASEF, 2003, at University of Nigeria, Nsukka. 
[16] Krishna, N (2001, June). Industrial potential of Enzyme in Waste Effluent treatment of industries. Bio-Energy Nes 5 (2): 1-10.

[17] Iloeje, O.C. (ed) (1998). Rural renewable Energy needs and five apply technology papers presented for the joint ECN-NYSC Rural Energy project.

[18] Itodo . I.O Onuh, C.E and Ogar, B.B (1995) Effect of various total solid concentration of cattle waste on biogas yields. Nigerian Journal of Energy, 13:36-39.

[19] Higgins, A and Konky, S (2002). Machine design: Carbon manopores for alternative fuel storage. Gale group, University of Missouri China,

[20] Obi, I. U (2001) Introduction to factorial experimental for agricultural, biological and Social Science Research ( $2^{\text {nd }}$ edn). Nigeria optimal publishers.

[21] NAS (1997). Methane generation from Human, animal and agricultural wastes. National Academy of Sciences, Washinton D.C.

[22] Miles and Misra (1938). Surface viable count method. A standard laboratory technique in pharmaceutics and pharmaceutical Microbiology.

[23] Prescott, M.L, John, P.H and Kler, D.A (1990). Applied Microbiology. USA: (WBC) Brown Publishers.

[24] Ofoefule, A.U and Chidimma, E.O.U. (2006). Optimization of the Qualitative biogas yield from poultry wastes, World Renewable Energy congress IX University of Florence. 